\title{
The tourism-led terrorism hypothesis - evidence from Italy, Spain, UK, Germany and Turkey
}

\author{
Maja Nikšić Radić \\ Department of International Economics and Development, \\ Faculty of Tourism and Hospitality Management, University of Rijeka \\ Opatija, Croatia \\ majann@fthm.hr \\ Daniel Dragičević \\ Department of Micro- and Macroeconomics, \\ Faculty of Tourism and Hospitality Management, University of Rijeka \\ Opatija, Croatia \\ danield@fthm.hr
}

\section{Marina Barkiđija Sotošek}

Department of Tourism,

Faculty of Tourism and Hospitality Management,

University of Rijek, a, Croatia

marinab@fthm.hr

Abstract. The aim of this study was to explore the causal relationship between terrorism and international tourism arrivals in several selected European tourist destinations. The main goal is to look at this issue from another perspective, i.e. whether the tourism-led terrorism hypothesis can be proved valid in addition to the already established terrorist-led tourism hypothesis. The study used econometric techniques such as the unit root test, the Granger causality test in a vector autoregressive model (VAR model), the analysis of variance decomposition and the impulse response function for the monthly time-series data from 2001 (1) to 2015 (12). Based on the research conducted, it was found that tourism Granger causes terrorism in Turkey, United Kingdom and Germany, while terrorism Granger causes tourism in Italy and Spain.

Keywords: tourism, terrorism, Granger causality, VAR, Turkey, United Kingdom, Germany, Italy, Spain.

JEL Classification: C22, D74, Z32 


\section{INTRODUCTION}

Tourism has been recognized as an economic driver throughout the world. According to WTTC (2017), in 2016, travel \& tourism directly contributed U.S \$2.3 trillion and 109 million jobs worldwide. Considering its wider indirect and induced impact, the sector contributed U.S $\$ 7.6$ trillion more to the global economy and supported an additional 292 million jobs in 2016. This is equal to $10.2 \%$ of the world's gross domestic product (GDP), and amounts to approximately 1 in 10 of all jobs.

Considering the fact that despite the continuous growth of terrorist attacks tourism records positive growth rates, the main objective of this paper is to investigate whether there is a possibility that tourism is a factor which attracts terrorism, and not that terrorism solely affects tourism. The survey was conducted on the data of five selected European destinations in the period from 2001 to 2015, with the largest number of international tourist arrivals falling in 2015 (UNWTO, 2016). The goal was set up following the Goldman \& Neubauer-Shani (2017) research which proved that international tourist arrivals have a positive impact on international tourism.

The main contribution of this paper is that the tourism-led terrorism hypothesis is tested which is extremely modestly represented in research studies. According to the author's knowledge, only Moik (2017) pointed out that 'the causal impact of terrorist attacks on tourism demand is not as straightforward' and he also found that in most cases 'the tourist numbers are not lower after an attack than before and even continue to grow after a terrorist attack had occured'. On the other hand, the terrorism-led tourism hypothesis is significantly represented in research (Afonso-Rodriguez, 2017; Enders \& Sandler, 1991; Feridun, 2011; Voltes-Dorta et al., 2016). Turkey, United Kingdom, Spain, Italy and Germany were selected for the analysis. These European destinations are among the top ten destinations, according to the World Tourism Organization data as of 2016. The paper focuses on these selected countries, given that their case studies are extremely important when investigating the impact of terrorism (Silke, 2004). In addition to the fact that each country has its own distinctiveness, the influence of terrorism varies, depending on whether it is a rich, large and diversified economy, or a small, poor and more specialized economy (Bandyopadhyay et al., 2015). The major difference from the already mentioned (Goldman \& Neubauer-Shani, 2017) research is seen in the fact that this work did not separate domestic and international terrorism (Ahlfeldt et al., 2015; Buigut \& Amendah, 2016), but it used aggregate terrorism incidents. The reason for this is that the image of a safe destination builds on an overall stability in the country, not just the influence of domestic or international terrorism (Arana \& León, 2008; Johnny \& Jordan, 2007).

This article is composed of five sections. After the introduction, the second section sets both empirical and theoretical frameworks and discusses the rationale behind the interweaving connection of tourism and terrorism, and the probability of proving the tourism-led terrorism hypothesis. In the third section, the data and methodology used are explained. The tourism-led terrorism hypothesis is tested and the findings are presented in the fourth section, followed by the conclusions.

\section{LITERATURE REVIEW}

Terrorism is one of the most global threats in the world. Over the last 16 years (2000-2016), the worst year in which acts of terrorism took place was 2014 with 93 countries experiencing an attack, and 32,765 people killed (Institute for Economics \& Peace, 2016). WTTC, (2016) report showed that compared to 2013, the number of deaths from terrorism in 2014 increased by 80\%. Furthermore, private citizens and properties remain the primary targets of terrorism, with a $172 \%$ increase in the number of private citizen deaths due to terrorist activities from 2013 to 2014. The global economic costs of terrorism reached U.S $\$ 52.9$ billion in 2014 , the highest ever, up from U.S $\$ 32.9$ billion in 2013. In 2016, 11,072 terrorist attacks occurred worldwide, resulting in more than 25,600 total deaths and more than 33,800 people injured 
(START, 2017a). The total number of terrorist attacks in 2016 decreased by $9 \%$ and total deaths due to terrorist attacks decreased by 13\% compared to 2015 .

Terrorism does not only induce depravation in life and economic loss, but also imposes social costs in a way that terrorist campaigns depress the life satisfaction of individuals in the affected regions in a sizeable way (Frey et al., 2009). Terrorists have often used tourists as targets because they are easy to attack and attract a lot of attention from the media.

Here are a few examples: the Luxor (Egypt) massacre, in which terrorists of the Islamic Group shot dead 58 foreign tourists visiting the temple of Queen Hatshepsut in the Valley of the Queens in 1997; the bombing of a disco in Bali in 2002, costing the lives of almost 200 mostly Australian tourists; the Sharm elSheikh (Egypt) bomb attacks on a bazaar in 2005, the Ghazala Gardens Hotel and a café resulting in the loss of 88 lives; the hotel bomb attack in Mombasa (Kenya) in 2002, resulting in 15 dead; Amman (Jordan) bombings on three hotels with 60 casualties, etc. (Ahlfeldt et al., 2015, p. 4; Buigut \& Amendah, 2016, p. 929; Frey, 2004, p. 17; Paraskevas \& Arendell, 2007, p. 1561).

Economists usually view terrorists as rational actors, i.e. based on the consumer-choice model, terrorists maximize utility or expected utility derived from the consumption of basic commodities, produced from terrorist and non-terrorist activities (Drakos \& Kutan, 2003; Enders et al., 1992; Enders \& Sandler, 1991, 1993).

On the other hand, countries try to deter such acts of violence. Based on the game theory, the deterrence aspect will not work if terrorists perceive a positive expected payoff from a terrorist attack. External costs are present for any country when domestic deterrence displaces an attack abroad, while external benefits are relevant when domestic deterrence either protects foreigners or reduces the level of attacks globally (Sandler \& Enders, 2004). Retaliation against terrorists provides both country-specific benefits and general benefits in all countries. The tendency for countries to retaliate is not only the payoff matrix between retaliating or not retaliating (free riding), but the option of paid riding must be considered, i.e. to retaliate against domestic terrorist groups while providing sanctuary to foreign terrorist groups (Lee \& Sandler, 1989; Lee, 1988).

According to the WTTC study, the impact of terrorism on tourism does not last long. To illustrate, it takes 13 months for tourism to recover from a terrorist attack, while it takes 21 months to recover from a disease, 24 months to recover from an environmental disaster and 27 months to recover from political unrest (Zillman, 2015). In their research of tourism and terrorism, scholars applied a qualitative (Fuchs et al., 2013; Korstanje \& Clayton, 2012; Morakabati \& Kapuscinski, 2016; Paraskevas \& Arendell, 2007; Wolff \& Larsen, 2014) and a quantitative approach (Ahlfeldt et al., 2015; Buigut \& Amendah, 2016; Enders \& Sandler, 1991; Fielding \& Shortland, 2011; Masinde et al., 2016; Raza \& Jawaid, 2013).

Although it seems that tourism and terrorism do not share any similarities, commonalities between them can be found - the usage of modern technology, dependency on the media, manipulation of perception and attitude (Korstanje \& Clayton, 2012). Terrorists target tourists, but tourists also visit terrorist attack sites (dark tourism).

Risk perception, together with attitudes and tourist income levels, are important when deciding where to visit (Sonmez \& Graefe, 1998). Deciding to go to a destination under a severe travel advisory may depend on risk perception, rationalizations with which tourists reduce their terror-related perceived risk, and political standpoint closely interconnected with risk perception (Fuchs et al., 2013). Morakabati \& Kapuscinski, (2016) found that the higher the importance attached to culture/heritage and nature/adventure benefits in the destination, the less risk averse tourists are. Contrary to that, if tourists attach a higher importance to seaside benefits, the less risk averse they are. Perceived risk may be influenced by difference baseline perceptions regarding a destination. The case of the 2011 Oslo/Utoya (Norway) massacre indicates a decline in risk perception and worries following the terrorist attack (Wolff \& Larsen, 2014). Authors state 
that in terror-ridden areas, terrorist attacks may lead to increased risk perception and worries. However, this need not be the case when the act of terror is committed by unorganized individuals in areas that are perceived to be safe to begin with.

Most of the quantitative studies researching tourism and terrorism have utilized a time series approach. Within this approach, scholars have used autoregressive integrated moving average (ARIMA) (Enders et al., 1992) and autoregressive moving average (ARMA) models (Muckley, 2010); vector autoregression (VAR) models (Enders \& Sandler, 1991), seemingly unrelated regression (SURE) models (Bassil, 2014; Drakos \& Kutan, 2003), autoregressive distributed lag (ARDL) models (Feridun, 2011; Masinde et al., 2016; Raza \& Jawaid, 2013), vector error-correction (VECM) (Feridun, 2011; Masinde et al., 2016) models and transfer function (Yaya, 2009).

Terrorism has a negative impact on revenue from tourism (Enders et al., 1992; Muckley, 2010) and it does not affect only one destination. There is evidence of spillover/substitution and regional effects (Bassil, 2014; Drakos \& Kutan, 2003).

Unidirectional causality from terrorism to tourism was confirmed for Spain (Enders \& Sandler, 1991), Pakistan (Raza \& Jawaid, 2013) and Turkey (Feridun, 2011). Enders \& Sandler, (1991) applied VAR on monthly data for Spain from 1970 to 1988 and identified negative unidirectional causality (terrorism $\rightarrow$ tourism). Authors estimated that a typical incident could scare away approximately 140,000 tourists when all monthly impacts are aggregated. Similarly, the ARDL approach for Pakistan, based on annual data (19812010), confirmed a unidirectional significant negative impact of terrorism on tourism in the long and in the short run (Raza \& Jawaid, 2013). Dynamic ordinary least square (DOLS) suggested that the results would remain the same in the future up to lead two. Feridun, (2011) researched Turkey by applying ARDL and VECM models on annual data from 1986 to 2006. The results obtained verified the long-term and shortterm negative causal effect of terrorism on tourism. Contrary to that, the case of Kenya suggested the absence of long-term equilibrium between terrorism and tourism (Masinde et al., 2016). Researchers used ARDL and VECM techniques and came to the conclusion that terrorism does not Granger cause tourism and vice versa. However, terrorism negatively affects tourism in the short run.

The previous decade has seen an increased number of research based on panel data. In their research, Yap \& Saha, (2013) utilized fixed-effects panel data analysis for 130 countries over the period from 1999 to 2009. They investigated the impact of political instability, terrorism, and corruption on tourism demand (proxied by tourist arrivals and revenue from tourism) where historical and natural UNESCO heritage is present. The research results indicated that a one-unit increase in political instability decreases tourist arrivals and revenue from tourism between $24 \%$ and $31 \%$ and $30 \%$ and $36 \%$, respectively. In addition, the results suggested that a high level of corruption reduces tourist arrivals significantly, while a one-unit increase in terrorist activity decreases tourist arrivals by $4-7 \%$.

Following their earlier research, Saha \& Yap, (2014) determined the moderation effects of political instability and terrorism on tourism development. They applied a fixed and random effects panel data analysis for 139 countries from 1999 to 2009, and a moderator effects regression analysis technique. The partial interaction effects of political instability and terrorism showed that political instability has a negative impact on tourism at higher terrorism risk levels, but the impact of terrorism provides some opposite results at a low and high level of political instability.

Ahlfeldt et al., (2015) analysed how German tourists react to unanticipated shocks that alter their risk perception of selected tourism destinations. Authors used a difference-in-difference approach to examine changes in tourism behaviour following 9/11 (2001), terror attacks in Egypt (1997), Tunisia (2002), Morocco (2003) and Indonesia (2003). The selected shocks heavily affected Islamic countries, indicating a transmission mechanism driven not only by geographic, but also by ethnic-religious proximity. Authors also noticed a temporary substitution effect in favour of (Southern) European countries. 
Spatial spillover effects in international tourism because of terrorist attacks was analysed in Neumayer \& Plümper, (2016). Authors used a spatial dyadic approach, and came to the following conclusions: terrorist attacks on tourist destinations in one country reduce the tourist flow to the targeted tourist destinations from the countries whose nation has been attacked; spatial spillover effects set in, reducing tourism flows from other similar source countries to the same destination country; tourism flows from the same source country to similar destination countries; tourism flows from similar source countries to similar destination countries.

The case of Kenya confirms earlier cited research that terrorism (proxied by the number of fatalities) negatively and significantly affects the number of visitors (Buigut \& Amendah, 2016). The authors implemented a dynamic panel data model on annual data from 2010 to 2013. The results indicated that a $1 \%$ increase in fatalities decreases tourist arrivals by about $0.13 \%$, which translates into a reduction in annual tourist earnings of about $\$ 1.82$ million. Research conducted by Llorca-Vivero, (2008) confirmed that both domestic and international tourism has a moderate, but significant negative impact on tourism. According to the author, in the case of 134 destinations analysed over the period 2001-2003, domestic victims and international events appear to have elasticities of around 0.07 and 0.15 respectively.

According to the literature available to the authors, so far only one piece of research has focused on whether tourism is the one that affects terrorism, and whether strong tourist destinations attract terrorist activities (Goldman \& Neubauer-Shani, 2017). Their main hypothesis was that the higher the number of international tourist arrivals to a country, the higher the number of terror attacks. The novelty of their work was in the analysis of four dependent variables: the number of terror attacks perpetrated by foreign attackers against local victims, number of terror attacks perpetrated by local attackers against foreign victims, number of terror attacks perpetrated by foreign attackers against foreign victims and number of terror attacks perpetrated against foreign private parties. The main independent variable used was international tourism followed by 12 control variables. The authors applied panel/zero-inflated negative binomial regression models of the incidence of transnational terrorism using a country-year database of 98-146 countries for 1995-2007. The results confirmed that international tourism, proxied by a number of arrivals, has a positive effect on transnational terrorism.

\section{METHODOLOGY}

This research employs monthly time series data from 2001(1) to 2015(12) in order to investigate the causal relationship between international tourist arrivals and terrorism in Turkey, United Kingdom, Spain, Italy and Germany. For the purpose of this analysis, five European countries that are on the list of top ten destinations of the World Tourism Organization with regard to the number of foreign visitors (UNWTO, 2016) were chosen. Even though the first idea was to include France in the analysis, authors decided to exclude it due to the incomplete data regarding the number of international tourist arrivals. The variable international tourist arrivals (ARR) has been obtained from the Eurostat database (Eurostat, 2018). A variable terrorism (TERR) has been obtained from The Global Terrorism Database (START, 2017b). The terrorism is measured by the number of incidents per month which is the most commonly used terrorism measure (Filer \& Stanišić, 2016). Both variables are in the logarithmic form and seasonally adjusted (Census $\mathrm{X}-12)$.

The empirical part of the work involves the use of econometric tests and models to examine the causal link between the selected variables. The causal investigation will include the implementation of the unit root test, the establishment of an adequate VAR model and ultimately the implementation of the Granger Cause Test. Within the set VAR model, a variance decomposition analysis will be carried out, as well as an impulse response function examination. 
As part of the evaluation of the VAR model, the following models are specified:

$$
\begin{gathered}
\operatorname{logiarr}_{t}=a_{0}+a_{1} \operatorname{logiarr}_{t-1}+\cdots+a_{p} \operatorname{logiarr}_{t-p}+b_{1} \operatorname{logterr}_{t-1}+\cdots+b_{p} \operatorname{logterr}_{t-p} \\
+u_{t} \\
\text { logterr }_{t}=c_{0}+ \\
\begin{array}{c}
c_{1} \operatorname{logterr}_{t-1}+\cdots+c_{p} \operatorname{logterr}_{t-p}+d_{1} \operatorname{logiarr}_{t-1}+\cdots+d_{p} \operatorname{logiarr}_{t-p} \\
+v_{t}
\end{array}
\end{gathered}
$$

where logiarr and logterr are logarithmic forms of the international tourist arrivals and terrorism, and $p$ is the optimal lag length.

\section{EMPIRICAL RESULTS AND DISCUSSION}

Stationary of the variables was tested for all time-series, and the results of the unit root test (ADF test)

\begin{tabular}{|c|c|c|c|c|c|c|}
\hline \multirow[b]{2}{*}{ Variable } & \multicolumn{3}{|c|}{ Level } & \multicolumn{3}{|c|}{ First difference } \\
\hline & Constant & $\begin{array}{c}\text { Constant and } \\
\text { Trend }\end{array}$ & None & Constant & $\begin{array}{c}\text { Constant and } \\
\text { Trend }\end{array}$ & None \\
\hline \multicolumn{7}{|c|}{ Turkey } \\
\hline logiarr_t & -1.09 & $-3.41 * *$ & 1.41 & $-18.80^{* * *}$ & $-18.73^{* * *}$ & $-18.67 * * *$ \\
\hline logterr_t & $-5.60 * * *$ & $-6.79 * * *$ & -1.14 & $-12.09 * * *$ & $-12.10^{* * *}$ & $-12.11 * * *$ \\
\hline \multicolumn{7}{|c|}{ United Kingdom } \\
\hline logiarr_uk & -1.26 & $-3.46 * *$ & 0.73 & $-14.98^{* * *}$ & $-14.96^{* * *}$ & $-14.98^{* * *}$ \\
\hline logterr_uk & $-2.68 *$ & -8.50 & -0.57 & $-10.37 * * *$ & $-10.43 * * *$ & $-10.39 * * *$ \\
\hline \multicolumn{7}{|c|}{ Spain } \\
\hline logiarr_s & -1.54 & -1.46 & 1.89 & $-13.41 * * *$ & $-13.41 * * *$ & $-13.18^{* * *}$ \\
\hline logterr_s & $-2.78^{* *}$ & $-11.28 * * *$ & $-2.24 * *$ & & & \\
\hline \multicolumn{7}{|c|}{ Italy } \\
\hline logiarr_i & -1.25 & $-4.00 * * *$ & 1.46 & $-11.74 * * *$ & $-11.71 * * *$ & $-11.61 * * *$ \\
\hline logterr_i & $-10.89 * * *$ & $-10.88^{* * *}$ & $-5.50 * * *$ & & & \\
\hline \multicolumn{7}{|c|}{ Germany } \\
\hline logiarr_g & -0.20 & $-3.66 * *$ & 1.38 & $-18.66^{* * *}$ & $-18.68^{* * *}$ & $-18.56 * * *$ \\
\hline logterr_g & $-5.50 * * *$ & $-8.87 * * *$ & -1.34 & $-10.91 * * *$ & $-10.89 * * *$ & $-10.94 * * *$ \\
\hline
\end{tabular}
in levels and first difference are shown in Table 1.

Table 1

ADF test result

The significance of the $\mathrm{p}$-value: ${ }^{* * *} \mathrm{p}<0.01,{ }^{*} \mathrm{p}<0.05,{ }^{*} \mathrm{p}<0.1$. Lag length in the model is based on the Schwarz information criterion. Abbreviations used for countries as follows _t (Turkey), _uk (United Kingdom), _s (Spain), _i (Italy), _g (Germany).

Source: Authors' calculations

The results of the ADF test point to the fact that logterr_s and logterr_ $i$ are stationary in level and logiarr_ $t$, logterr_t, logiarr_uk, logterr_uk, logiarr_s, logiarr_i, logiarr_g and logterr_g are stationary after the first difference. Thus, it is possible to conclude that all the observed series do not contain the unit root given that the zero hypothesis for non-stationarity has been rejected. To ensure the reliability of the VAR model, the next step was to choose the optimal lag length of the VAR models. The optimal number of lags was chosen with the help of the usual information criteria (Akaike, Schwarz and Hannan-Quinn), but also by checking the dynamic stability of the VAR models. 
Table 2 shows the results of the lag length selection criteria through the usual information criteria, and the final evaluation of the optimal lag length based on the quality of the models themselves.

Table 2

Lag length selection

\begin{tabular}{|l|c|c|}
\hline & VAR Lag Order Selection & Optimal lag length \\
\hline Causality between logiarr_t and logterr_t $t$ & 2 & 3 \\
\hline Causality between logiarr_uk and logter__uk & $2 / 3 / 6$ & 3 \\
\hline Causality between logiarr_s and logter__s & $3 / 5 / 7$ & 5 \\
\hline Causality between logiarr_i and logterr_ $i$ & $3 / 5$ & 5 \\
\hline Causality between logiarr_g and logterr_g & $3 / 7$ & 4 \\
\hline
\end{tabular}

Source: Authors' calculations

The optimal lag length selection for Turkey is 4, United Kingdom 6, Spain 7, Italy 5 and Germany 5. The dynamic stability of the VAR models of the researched countries is shown in Figure 1.

logiarr_t and logterr_t

Inverse Roots of AR Characteristic Polynon

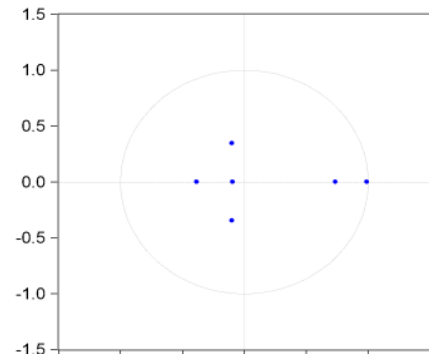

logiarr_ $i$ and logterr_ $i$

Inverse Roots of AR Characteristic Polynon

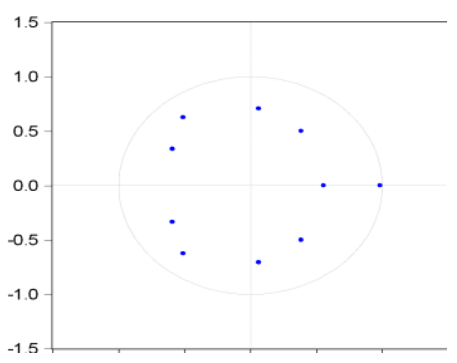

logiarr_uk and logterr_uk

Inverse Roots of AR Characteristic Polynon

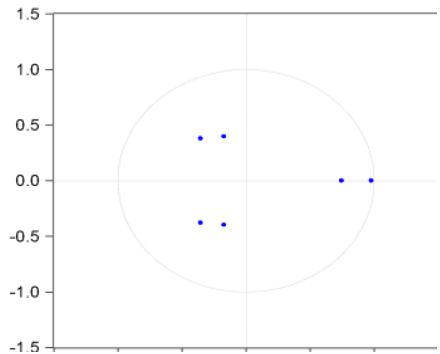

logiarr $g$ and logterr $g$

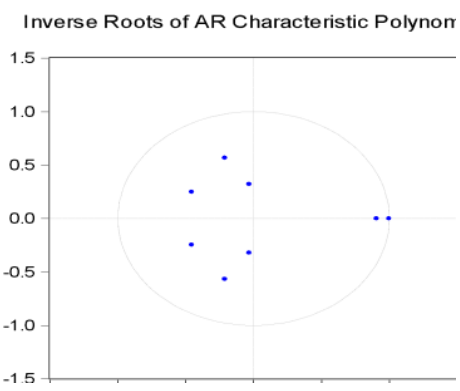

logiarr_s and logterr_s

Inverse Roots of AR Characteristic Polynom

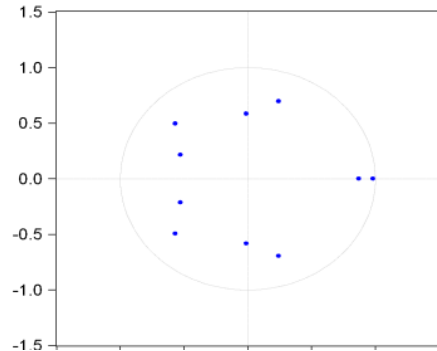

Figure 1. Stability of the VAR model

Source: Authors' calculations

Due to the fact that none of the roots are outside the circles, it is possible to conclude that the VAR models are stable, which means that the results and conclusions following from further analysis are not questionable. The next step is to test the Granger causality relationship. Classic Granger causality involves performing a Wald test for the first p parameters of other variables in the VAR model, and, if the Wald test was significant, rejecting the null hypothesis of no causality. The results of the test are shown in Table 3 . 
Granger causality test

\begin{tabular}{|l|l|c|c|}
\hline Country & Null hypothesis & $\chi^{2}$ test & p-value \\
\hline \multirow{3}{*}{ Turkey } & IARR_T does not Granger cause TERR_T & $6.289334^{*}$ & $\mathbf{0 . 0 9 8 4}$ \\
\cline { 2 - 4 } & TERR_T does not Granger cause IARR_T & 3.615850 & 0.3060 \\
\hline \multirow{3}{*}{ United Kingdom } & IARR_UK does not Granger cause TERR_UK & $11.96064^{* * *}$ & $\mathbf{0 . 0 0 7 5}$ \\
\cline { 2 - 4 } & TERR_UK does not Granger cause IARR_UK & 3.601396 & 0.3078 \\
\hline \multirow{2}{*}{ Spain } & IARR_S does not Granger cause TERR_S & 3.905430 & 0.5631 \\
\cline { 2 - 4 } & TERR_S does not Granger cause IARR_S & $9.842304^{*}$ & $\mathbf{0 . 0 7 9 8}$ \\
\hline \multirow{2}{*}{ Italy } & IARR_I does not Granger cause TERR_I & 6.583609 & 0.2535 \\
\cline { 2 - 4 } & TERR_I does not Granger cause IARR_I & $10.12956^{*}$ & $\mathbf{0 . 0 7 1 6}$ \\
\hline \multirow{2}{*}{ Germany } & IARR_G does not Granger cause TERR_G & $8.468593 *$ & $\mathbf{0 . 0 7 5 8}$ \\
\cline { 2 - 4 } & TERR_G does not Granger cause IARR_G & 2.961500 & 0.5643 \\
\hline
\end{tabular}

The significance of $\mathrm{p}$-value: ${ }^{* * *} \mathrm{p}<0.01,{ }^{*} \mathrm{p}<0.05,{ }^{*} \mathrm{p}<0.1$.

Source: Authors' calculations

The results have shown that the first null hypothesis 'IARR non-cause TERR' could not be rejected, i.e. it could not be concluded that the international tourist arrivals affect terrorism in Spain and Italy. The second null hypothesis 'TERR non-cause IARR' could not be rejected, i.e. it could not be concluded that terrorism has a causal link with international tourist arrivals in the United Kingdom, Turkey and Germany. It may be concluded that international tourist arrivals cause terrorism in Granger's sense in the case of the United Kingdom, Turkey and Germany, while terrorism causes international tourist arrivals in the Granger's sense in the case of Spain and Italy.

The variance decomposition of the variables 'IARR' and 'TERR' was conducted for the prognostic period of the following 24 months. The variance decomposition shows the relative share of individual variables in the explanation of the variance of the second variable in the following periods. The results of the test are shown in Table 4.

At the level of Turkey, IARR fully explains its prognostic error when it comes to the first future period. After two years, this percentage drops to $99.49 \%$. As far as TERR is concerned, it also almost completely explains its prognosis error in the first future period, and after two years, this percentage drops slightly to $94.20 \%$. It is possible to conclude that IARR affects the explained TERR prognostic errors.

The variance decomposition in the example of the United Kingdom shows that in the first period IARR explains $100 \%$ of its prognostic errors. After two years, this percentage drops down negligibly and amounts to $99.60 \%$. The TERR variable in the first period explains $98.71 \%$ of its prognostic error, but after two years, this percentage drops to $70.48 \%$. Obviously, IARR affects the explanation of the TERR prognostic error.

In the case of Spain, the variance decomposition shows that IARR explains $100.00 \%$ of its prognostic errors in the first period. After two years, this percentage drops to $91.61 \%$ and it is obvious that TERR affects the explanation of the IARR prognostic error. Looking at the TERR variable, it is possible to conclude that it explains $99.95 \%$ of its prognostic error in the first period, and after two years this percentage drops to $97.58 \%$. 
Table 4

Variance decomposition

\begin{tabular}{|c|c|c|c|c|c|}
\hline \multirow{2}{*}{ Variance period } & \multirow{2}{*}{ Country } & \multicolumn{2}{|c|}{ Variance decomposition of IARR } & \multicolumn{2}{|c|}{ Variance decomposition of TERR } \\
\hline & & IARR & TERR & IARR & TERR \\
\hline 1 & \multirow{5}{*}{$\begin{array}{c}\text { TURKE } \\
Y\end{array}$} & 100.00 & 0.00 & 0.01 & 99.99 \\
\hline 6 & & 98.85 & 1.15 & 2.34 & 97.66 \\
\hline 12 & & 99.23 & 0.77 & 3.69 & 96.31 \\
\hline 18 & & 99.40 & 0.60 & 4.82 & 95.18 \\
\hline 24 & & 99.49 & 0.51 & 5.80 & 94.20 \\
\hline 1 & \multirow{5}{*}{$\begin{array}{c}\text { UNITE } \\
\text { D } \\
\text { KINGD } \\
\text { OM }\end{array}$} & 100.00 & 0.00 & 1.29 & 98.71 \\
\hline 6 & & 99.15 & 0.85 & 9.17 & 90.83 \\
\hline 12 & & 99.44 & 0.56 & 18.47 & 81.53 \\
\hline 18 & & 99.55 & 0.45 & 25.06 & 74.94 \\
\hline 24 & & 99.60 & 0.40 & 29.52 & 70.48 \\
\hline 1 & \multirow[t]{5}{*}{ SPAIN } & 100.00 & 0.00 & 0.05 & 99.95 \\
\hline 6 & & 96.36 & 3.64 & 1.02 & 98.98 \\
\hline 12 & & 95.28 & 4.72 & 1.54 & 98.46 \\
\hline 18 & & 93.37 & 6.63 & 2.00 & 98.00 \\
\hline 24 & & 91.61 & 8.39 & 2.42 & 97.58 \\
\hline 1 & \multirow[t]{5}{*}{ ITALY } & 100.00 & 0.00 & 3.64 & 96.36 \\
\hline 6 & & 97.67 & 2.33 & 5.57 & 94.43 \\
\hline 12 & & 97.24 & 2.76 & 4.74 & 95.26 \\
\hline 18 & & 97.06 & 2.94 & 4.09 & 95.91 \\
\hline 24 & & 96.96 & 3.04 & 3.66 & 96.34 \\
\hline 1 & \multirow{5}{*}{$\begin{array}{c}\text { GERMA } \\
\text { NY }\end{array}$} & 99.91 & 0.09 & 0.00 & 100.00 \\
\hline 6 & & 98.98 & 1.02 & 1.68 & 98.32 \\
\hline 12 & & 98.92 & 1.07 & 1.80 & 98.20 \\
\hline 18 & & 98.83 & 1.17 & 3.20 & 96.80 \\
\hline 24 & & 98.73 & 1.27 & 5.57 & 94.43 \\
\hline
\end{tabular}

Source: Authors' calculations

The variant decomposition in the example of Italy shows that IARR explains $100.00 \%$ of its prognostic error in the first period, and after two years this percentage drops to $96.96 \%$. The TERR variable in the first period explains $96.36 \%$ of its prognostic errors, and this percentage after two years remains practically the same, at $96.34 \%$.

In the example of Germany, IARR almost fully explains its prognostic error as far as the first future period is concerned. After two years this percentage drops to $98.73 \%$ and it is possible to conclude that TERR does not affect the explanation of the IARR prognostic error. As far as TERR is concerned, in the first future period, it completely explains its prognostic error, and after two years this percentage drops to $94.43 \%$.

Finally, impulse response functions are calculated as the reaction of each endogenous variable to unit shock in system variables.

The generalized impulse response function plotted in Figure 2 shows that one-standard-deviation changes in LOGIARR_T cause the LOGTERR_T to increase especially in the following five periods. After that, it still slightly positively affects terrorism in future periods. On the other hand, the shock of one standard deviation in LOGTERR_T has a slightly negative effect on LOGIARR_T in the following two periods, after which it starts to disappear. 


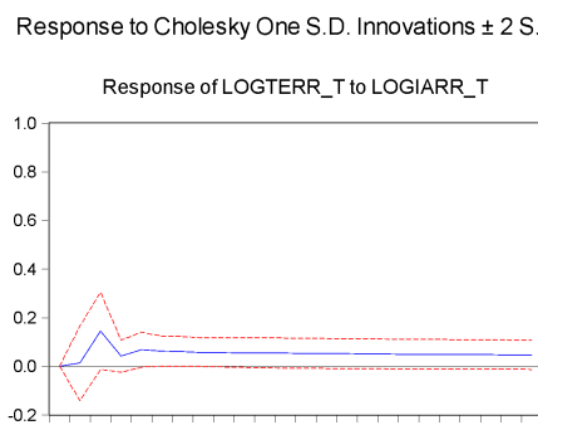

Response to Cholesky One S.D. Innovations \pm 2 S

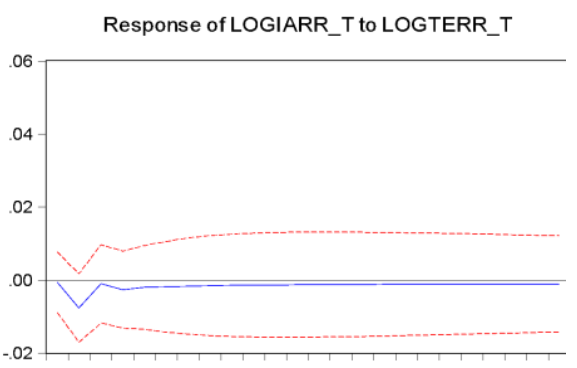

Figure 2. The impulse response of international tourist arrivals and terrorism in Turkey Source: Authors' calculations

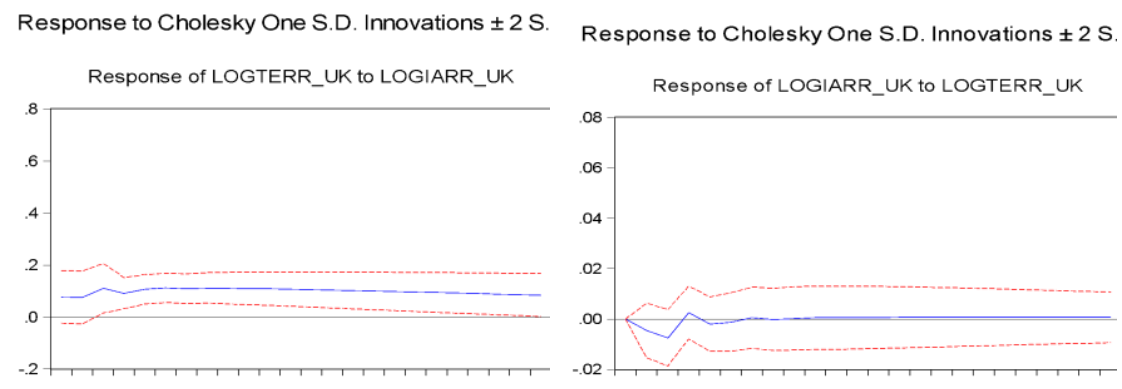

Figure 3. The impulse response of international tourist arrivals and terrorism in the United Kingdom

Source: Authors' calculations

An increase of LOGIARR_UK by one standard deviation changes has a constant positive effect on LOGTERR_UK. Also, there is a slightly negative impact of the shock of one standard deviation in LOGTERR_UK on LOGIARR_UK in the following two periods, after which it has an almost neutral effect.
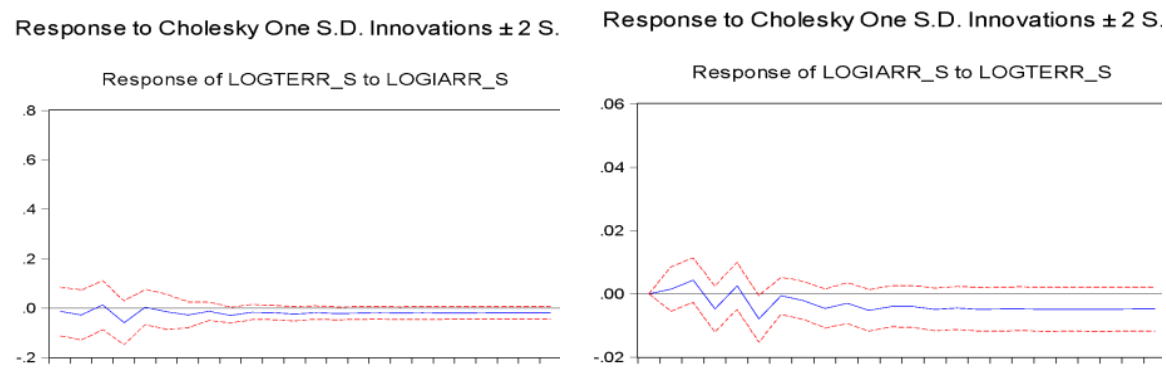

Figure 4. The impulse response of international tourist arrivals and terrorism in Spain Source: Authors' calculations

The shock of one standard deviation changes in LOGIARR_S has an almost neutral effect on LOGTERR_S. On the other hand, the shock of one standard deviation in LOGTERR_S has a constant negative effect on LOGIARR_S. 

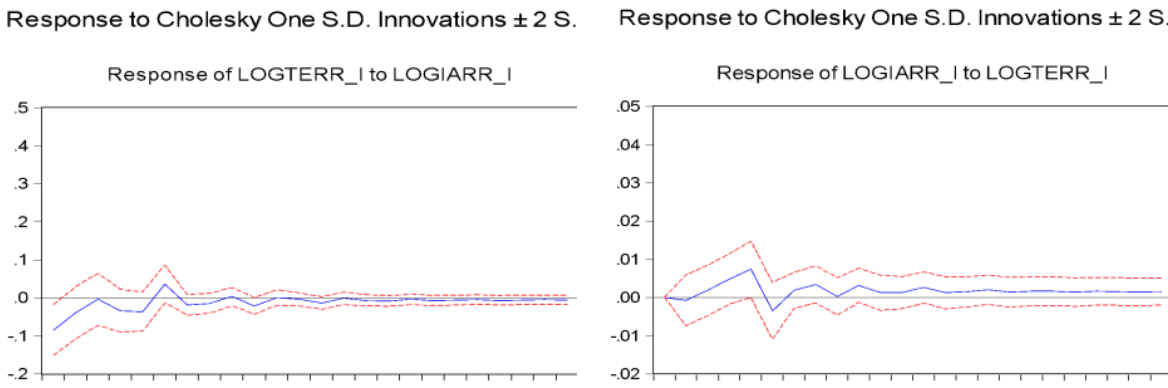

Figure 5. The impulse response of international tourist arrivals and terrorism in Italy Source: Authors' calculations

An increase of LOGIARR_I by one standard deviation changes has a slightly negative, almost neutral effect on LOGTERR_I. Also, there is a slightly negative impact of the shock of one standard deviation in LOGTERR_I on LOGIARR_I in the following ten periods, except during the fifth period when the impact is slightly positive.
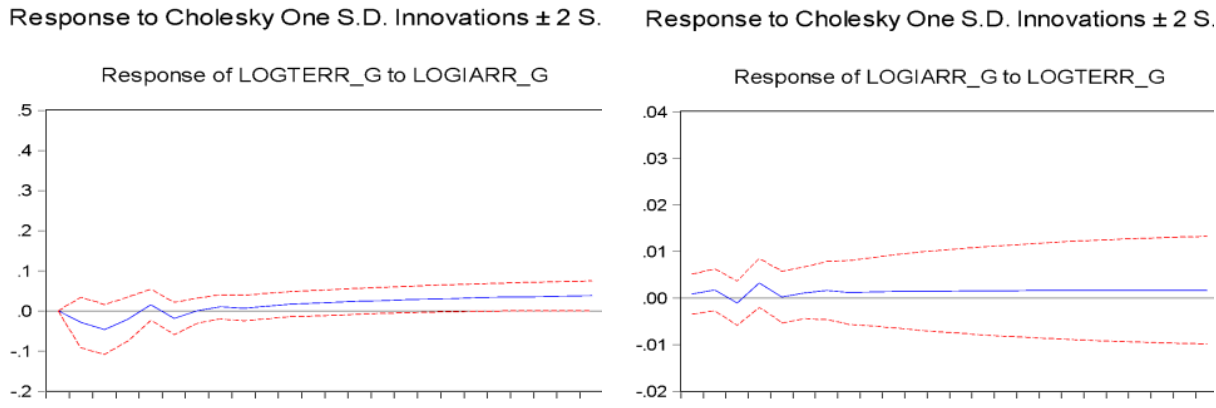

Figure 6. The impulse response of international tourist arrivals and terrorism in Germany

Source: Authors' calculations

An increase of one-standard deviation changes in LOGIARR_G has a slightly positive effect on LOGTERR_G. On the other hand, the shock of one standard deviation in LOGTERR_G has a slightly positive effect on LOGIARR_G.

The implementation of Granger's Cause Test, Variant Decomposition Analysis, and Impulse Response Functions resulted in the following results: in the example of Turkey, UK and Germany, there is a causal link in the direction of variables of foreign tourist arrivals towards variables of terrorism; the variable of foreign tourist arrivals explains some of the prognostic errors of terrorism variables; the increase in foreign tourist arrivals for one standard deviation leads to an increase in terrorism. In addition, in the case of Spain and Italy, there is a causal link in the direction of the variance of terrorism to the variables of foreign tourist arrivals; the terrorism variable explains part of the prognostic errors of the foreign tourist arrivals variable and the increase of terrorism for one standard deviation leads to a reduction in foreign tourist arrivals. 


\section{CONCLUSION}

This paper deals with the empirical research on the causal link between terrorism and foreign tourist arrivals on the example of selected European tourist destinations such as Turkey, UK, Spain, Italy and Germany. Unlike most previous studies, the paper starts with the assumption that it is necessary to test the 'tourism-led terrorism' hypothesis alongside the generally accepted 'terrorism-led tourism' hypothesis.

The empirical analysis was conducted using the Granger Causality test, the variance decomposition and the Impulse Response Function. The results of the research have led to the conclusion that, along with the 'terrorism-led tourism' hypothesis as demonstrated by the example of Spain and Italy, it is possible to speak of a 'tourism-led terrorism' hypothesis, as demonstrated by the example of Turkey, the UK and Germany.

Research results are also in line with the research conducted so far, which maintains that terrorism affects the number of international tourist arrivals (Bassil, 2014; Buigut \& Amendah, 2016; Drakos \& Kutan, 2003; Enders et al., 1992; Enders \& Sandler, 1991), but they also pointed to the need to appreciate the possibility that the number of international tourist arrivals affects terrorism, which, according to the authors' findings, was only investigated by Goldman \& Neubauer-Shani, (2017). The latest results from WTTC, (2017) are in favour of the tested hypothesis, saying that in 2016, global tourism grew by $3.3 \%$ despite ongoing terrorist threats.

Among the issues for future research, the authors believe that the connection between tourism and terrorism should be observed as a mutual relationship, given that the latest research results point to this need. Also, more case studies need to be carried out having in mind the particularity of each country.

The contribution of this article is twofold: it tests the tourism-led terrorism hypothesis using the case study of the selected countries and it establishes the need to further investigate the relationship leading from tourism to terrorism. The need to research individual countries comes from the specificities of each tourist destination and the possible different effects. According to Yaya, (2009), the nature and characteristics of terrorism differ across countries. In the case of Turkey, UK and Germany, it seems there is an issue related to attracting terrorist attacks, while the case of Spain and Italy points to a different conclusion.

As far as political implications are concerned, each country needs to provide an adequate policy aimed at combating terrorism, which will create a positive picture on the tourist map, as the fact is that after a terrorist attack, tourists only delay their spending from one period to the next (Economist, 2015). Political leaders of each country should be focused on maintaining a low to moderate political risk which ensures that the country, despite terrorism, achieves positive tourist results (Yap \& Saha, 2013).

\section{ACKNOWLEDGEMENT}

This work was supported by the University of Rijeka under the Grant ZP UNIRI 8/16

\section{REFERENCES}

Afonso-Rodriguez, J. A. (2017). Evaluating the dynamics and impact of terrorist attacks on tourism and economic growth for Turkey. Journal of Policy Research in Tourism, Leisure and Events, 9(1), 56-81. https://doi.org/10.1080/19407963.2016.1231196

Ahlfeldt, G. M., Franke, B. \& Maennig, W. (2015). Terrorism and International Tourism: The Case of Germany. Journal of Economics and Statistics, 235(1), 3-21. https://doi.org/10.1515/jbnst-2015-0103

Arana, J. E. \& León, C. J. (2008). The impact of terrorism on tourism demand. Annals of Tourism Research, 35(2), 299315. https://doi.org/10.1016/j.annals.2007.08.003

Bandyopadhyay, S., Sandler, T. \& Younas, J. (2015). The Toll of Terrorism. Finance \& Development, 52(2), 27. Retrieved from http://www.imf.org/external/pubs/ft/fandd/2015/06/bandyopa.htm 
Bassil, C. (2014). The Effect of Terrorism on Tourism Demand in the Middle East. Peace Economics, Peace Science, and Public Policy, 20(4), 16. https://doi.org/10.1515/peps-2014-0032

Buigut, S. \& Amendah, D. D. (2016). Effect of terrorism on demand for tourism in Kenya. Tourism Economics, 22(5), 928-938. https://doi.org/10.5367/te.2015.0467

Drakos, K. \& Kutan, A. M. (2003). Regional effects of terrorism on tourism in three Mediterranean countries. Journal of Conflict Resolution, 47(5), 621-641. https://doi.org/10.1177/0022002703258198

Economist. (2015). Why terrorism has a limited impact on markets. Retrieved November 12, 2017, from https://www.economist.com/blogs/buttonwood/2015/11/investing

Enders, W. \& Sandler, T. (1991). Causality between transnational terrorism and tourism: The case of Spain. Studies in Conflict \& Terrorism, 14(1), 49-58. https://doi.org/10.1080/10576109108435856

Enders, W. \& Sandler, T. (1993). The effectiveness of antiterrorism policies: A vector-autoregression-intervention analysis. American Political Science Review, 87(4), 829-844. https://doi.org/10.2307/2938817

Enders, W., Sandler, T. \& Parise, G. F. (1992). An Econometric Analysis of the Impact of Terrorism on Tourism. Kyklos, 45(4), 531-554. https://doi.org/10.1111/j.1467-6435.1992.tb02758.x

Eurostat. (2018). Eurostat database / Tourism. Retrieved February 28, 2018, from http://ec.europa.eu/eurostat/data/database

Feridun, M. (2011). Impact of terrorism on tourism in Turkey: empirical evidence from Turkey. Applied Economics, 43(24), 3349-3354. https://doi.org/10.1080/00036841003636268

Fielding, D. \& Shortland, A. (2011). How do tourists react to political violence? An empirical analysis of tourism in Egypt. Defence and Peace Economics, 22(2), 217-243. https://doi.org/10.2139/ssrn.1640489

Filer, R. K. \& Stanišić, D. (2016). The effect of terrorist incidents on capital flows. Review of Development Economics, 20(2), 502-513. https://doi.org/10.1111/rode.12246

Frey, B. (2004). Dealing with terrorism: stick or carrot? Cheltenham, UK: Edward Elgar Publishing.

Frey, B., Luechinger, S. \& Stutzer, A. (2009). The life satisfaction approach to valuing public goods: The case of terrorism. Public Choice, 138(3), 317-345. https://doi.org/10.1007/s11127-008-9361-3

Fuchs, G., Uriely, N., Reichel, A. \& Maoz, D. (2013). Vacationing in a terror-stricken destination: Tourists' risk perceptions and rationalizations. Journal of Travel Research, 52(2), $182-191$. https://doi.org/10.1177/0047287512458833

Goldman, O. S. \& Neubauer-Shani, M. (2017). Does international tourism affect transnational terrorism? Journal of Travel Research, 56(4), 451-467. https://doi.org/10.1177/0047287516649059

Institute for Economics \& Peace. (2016). Global Terrorism Index 2016. Retrieved September 16, 2017, from http://visionofhumanity.org/app/uploads/2017/02/Global-Terrorism-Index-2016.pdf

Johnny, L. \& Jordan, L.-A. (2007). Tourism and Crime in the Caribbean: A case study of St Lucia. Annals of Leisure Research, 10(3-4), 475-497. https://doi.org/10.1080/11745398.2007.9686777

Korstanje, M. E. \& Clayton, A. (2012). Tourism and terrorism: conflicts and commonalities. Worldwide Hospitality and Tourism Themes, 4(1), 8-25. https://doi.org/10.1108/17554211211198552

Lee, D. (1988). Free Riding and Paid Riding in the Fight against Terrorism. American Economic Review, 78(2), $22-26$. Retrieved from http://econpapers.repec.org/scripts/redir.pfu=http $\% 3 \mathrm{~A} \% 2 \mathrm{~F} \% 2$ Flinks.jstor.org\%2Fsici\%3Fsici $\% 3 \mathrm{D} 0002$ $8282 \% 2528198805 \% 252978 \% 253$ A2\%253C22\%253AFRAPRI $\% 253$ E2.0.CO $\% 253$ B2-

B\%26origin\%3Drepec;h=repec:aea:aecrev:v:78:y:1988:i:2:p:22-26

Lee, D. \& Sandler, T. (1989). On the optimal retaliation against terrorists: The paid-rider option. Public Choice, 61(2), 141-152. https://doi.org/10.1007/bf00115660

Llorca-Vivero, R. (2008). Terrorism and international tourism: New evidence. Defence and Peace Economics, 19(2), 169188. https://doi.org/10.1080/10242690701453917

Masinde, B. K., Buigut, S. \& Mungatu, J. K. (2016). Modelling the Temporal Effect of Terrorism on Tourism in Kenya. International Journal of Economics and Finance, 8(12), 10. https://doi.org/doi:10.5539/ijef.v8n12p10

Moik, C. (2017). The Terrorism-Tourism Nexus - The Causal Impact of Terrorist Attacks on Tourism Demand. Retrieved April 30, 2018, from https://cmdataresearch.com/2017/10/09/the-terrorism-tourism-nexus/ 
Morakabati, Y. \& Kapuscinski, G. (2016). Personality, risk perception, benefit sought and terrorism effect. International Journal of Tourism Research, 18(5), 506-514. https://doi.org/10.1002/jtr.2068

Muckley, C. B. (2010). Terrorism, Tourism and FDI: Estimating a lower bound on the Peace Dividend in Northern Ireland. SSRN Electronic Journal. https://doi.org/10.2139/ssrn.1689510

Neumayer, E. \& Plümper, T. (2016). Spatial spill-overs from terrorism on tourism: Western victims in Islamic destination countries. Public Choice, 169(3-4), 195-206. https://doi.org/10.1007/s11127-016-0359-y

Paraskevas, A. \& Arendell, B. (2007). A strategic framework for terrorism prevention and mitigation in tourism destinations. Tourism Management, 28(6), 1560-1573. https://doi.org/10.1016/j.tourman.2007.02.012

Raza, S. A. \& Jawaid, S. T. (2013). Terrorism and tourism: A conjunction and ramification in Pakistan. Economic Modelling, 33, 65-70. https://doi.org/10.1016/j.econmod.2013.03.008

Saha, S. \& Yap, G. (2014). The moderation effects of political instability and terrorism on tourism development: A cross-country panel analysis. Journal of Travel Research, 53(4), 509-521. https://doi.org/10.1177/0047287513496472

Sandler, T. \& Enders, W. (2004). An economic perspective on transnational terrorism. European Journal of Political Economy, 20(2), 301-316. https://doi.org/10.1016/j.ejpoleco.2003.12.007

Silke, A. (2004). Research on terrorism: Trends, achievements and failures. Routledge.

Sonmez, S. F. \& Graefe, A. R. (1998). Influence of terrorism risk on foreign tourism decisions. Annals of Tourism Research, 25(1), 112-144. https://doi.org/10.1016/s0160-7383(97)00072-8

START. (2017a). Annex of Statistical Information Country /Reports on Terrorism 2016. Retrieved September 12 , 2017, from https://www.state.gov/documents/organization/272485.pdf

START. (2017b). Global Terrorism Database (Data file). Retrieved January 8, 2018, from https://www.start.umd.edu/gtd

UNWTO. (2016). UNWTO Tourism Highlights 2016. Retrieved August 2, 2017, from http://www.eunwto.org/doi/pdf/10.18111/9789284418145

Voltes-Dorta, A., Jiménez, J. L. \& Suárez-Alemán, A. (2016). The impact of ETA’s dissolution on domestic tourism in Spain. Defence and Peace Economics, 27(6), 854-870. https://doi.org/10.1080/10242694.2015.1025485

Wolff, K. \& Larsen, S. (2014). Can terrorism make us feel safer? Risk perceptions and worries before and after the July 22nd attacks. Annals of Tourism Research, 44, 200-209. https://doi.org/10.1016/j.annals.2013.10.003

WTTC. (2016). Tourism as a driver of peace. Retrieved September 16, 2017, from https://www.wttc.org//media/files/reports/special-and-periodic-reports/tourism-as-a-driver-of-peace-full-report-copyrighted.pdf

WTTC. (2017). Global Economic Impact \& Issues 2017. Retrieved September 16, 2017, from https://www.wttc.org//media/files/reports/economic-impact-research/2017-documents/global-economic-impact-and-issues2017.pdf

Yap, G. \& Saha, S. (2013). Do political instability, terrorism, and corruption have deterring effects on tourism development even in the presence of UNESCO heritage? A cross-country panel estimate. Tourism Analysis, 18(5), 587-599. https://doi.org/10.3727/108354213x13782245307911

Yaya, M. E. (2009). Terrorism and tourism: The case of Turkey. Defence and Peace Economics, 20(6), 477-497. https://doi.org/10.1080/10242690903105414

Zillman, C. (2015). Terrorism's Effect on Tourism Doesn't Last Very Long. Retrieved September 16, 2017, from http:/ fortune.com/2015/11/30/terrorism-tourism-paris/ 